\title{
Canada's Neglected Tradition of Coalition Government
}

\section{James Muir*}

On Wednesday, 26 November 2008, I closed the second of two lectures on politics in the 1840 s and 1850s for my second-year, pre-Confederation Canadian history students by reiterating the definition of responsible government. I suggested that, at its core, was the principle that the parliamentary executive was responsible to the elected assembly as a whole, and that the governor general (or lieutenant governor) was expected to follow the executive's wishes. This expectation included not calling elections every time a government fell in the assembly, but rather selecting another government that had the support of the already elected members of the assembly.

I continued by noting that the principles of responsible government remain the basis of Canadian democracy, although these principles have little practical effect, except at moments of crisis like the King-Byng affair. I suggested that the students would be unlikely to see the principles in action. By my Friday class, the conclusions I had made two days earlier seemed no longer valid. Indeed, on that morning of 28 November and on the following Monday, 1 December, while I discussed with my classes the lead-up to Confederation from before the Charlottetown conference of 1864 through to 1 July 1867, Canadians were confronted with their Prime Minister postponing a confidence vote in the House of Commons, even as opposition parties were forging a coalition agreement.

At first, the events of late November and early December 2008 excited me as a teacher because they provided me with a contemporary example of responsible government in action: here was a perfect opportunity to understand continuity in political theory and political history. Of course, most of the discussion about the proposed coalition took place in public, not in classrooms like mine. As the public discourse about the coalition evolved, three distinct threads of debate became apparent: legality, legitimacy, and precedent.

First, there was a great deal of discussion about whether or not it was legal to make the coalition the government without an election. Related to this were two discussions of its legitimacy. One stream portrayed the Liberal-New Democratic Party coalition proposal as antidemocratic because it was not part of either party's election platform, and so had not received popular sanction in the October 2008 general election. A second stream asserted that the inclusion of the Bloc Québécois in the coalition agreement meant that the Liberal Party and New Democratic Party (NDP) were trying to bring separatists into the national government. Finally, public discourse frequently drew from the example of previous coalition governments, including: the NDP-Liberal coalitions in Saskatchewan, 1999-2003, and Ontario, 1985-7; the Liberal-Progressive coalition in the 1920s; and the Union government during the First World War. Lecturing about Confederation convinced me that all three of these threads were faulty.

To demonstrate this, it is necessary to briefly recount one of the germinal events of Confederation. ${ }^{1}$ The famous photographs and paintings of Confederation show the Charlottetown conference in the summer in 1864 , and its immediate successor at Québec in the autumn. It was at these conferences that the initial agreement among the colonial governments to confederate was reached, and the elemental division between federal and provincial jurisdictions was decided. The Charlottetown conference was originally organized for the At- 
lantic colonies alone, but upon request included a delegation from Canada, which brought with it a proposal for the union of all of the central and eastern colonies of British North America. The Canadian delegation represented Canada's new government of June 1864, formed in part to bring about confederation (or some other constitutional change). That government is now often called the "Great Coalition" or "Canadian Coalition," and was a coalition formed under the leadership of John A. Macdonald, Alexander Galt, George-Étienne Cartier, and George Brown (although, nominally, the premier was Étienne Taché).

Coalition government had been routine since the union of Upper and Lower Canada in 1841. The nascent political parties of the colony were often, although not always, divided along the old colonial boundaries. In the twenty-three years leading up to late June 1864 there were seventeen governments, most of which were coalitions of more-or-less like-minded parties from the two halves; generally speaking, these governments shared leadership with one senior minister from each side together performing most of the premier's tasks. There were, however, only seven elections during this period. It is worth quickly running through this history: following the 1841 election in Canada, Lord Sydenham appointed Robert Baldwin and William Draper as leaders of a coalition government. Baldwin resigned prior to the first Parliament. Draper continued on his own until 1842, when he was replaced by Baldwin and Louis-Hippolyte Lafontaine. In 1843, they were replaced by Dominic Daley. An election in 1844 resulted in a Draper-Denis Viger coalition, which was replaced by a Draper-Louis Papineau coalition in 1845. In 1847, Draper resigned to be replaced by Henry Sherwood. After the election that followed, Baldwin and Lafontaine began a new government. They resigned in 1851 and were replaced by a government led by Francis Hincks and Augustin Morin, which was then confirmed by an election. In 1854, another election year, Hincks resigned and was replaced by Alan McNab. Three months later Morin resigned to be replaced by Étienne Taché. $\mathrm{McNab}$ resigned in 1856 and was replaced by John A. Macdonald; Taché resigned in 1857 to be replaced by George-Étienne Cartier. The Macdonald-Cartier government was briefly replaced in 1858 by George Brown and A.A. Dorion, but this coaltion was quickly brought down and replaced by a new Macdonald-Cartier government that survived the 1858 election, and persisted until after the 1861 election when it was replaced by J.S. Macdonald ${ }^{2}$ and Louis Sicotte. After the 1863 election, Sicotte was replaced by Dorion, and the J.S. MacdonaldDorion government lasted until March 1864. It was replaced by a new Taché-John A. Macdonald government for two-and-a-half months, which was then replaced by the Great Coalition under Taché. After Taché's death in 1865, a coalition led by John A. Macdonald and Narcisse Belleau governed, without Brown, until 1867. ${ }^{3}$ Clearly, shifting coalitions and changing governments were regular features of the history of the united Canadas. Elections, more often than not, did not mark significant changes in rule. After 1848, changes in government occurred when the government no longer had the support of the assembly; elections generally served to perpetuate already established coalitions, or to change only one part of the leadership. The history of the united Canadas from 1841 to 1867 shows that, for some time, coalition was not an aberration in Canadian history but rather a regular part of government.

Despite all of the previous coalitions, the Great Coalition of 1864 was peculiar. The makeup of this government should have given pause, I think, to those who asserted that the proposals of November and December 2008 were illegitimate because they were not part of any party's platform or because they involved, in a limited way, Québec nationalists who may be seeking the constitutional reorganization of northern North America. The Great Coalition of June 1864 was special, even given the frequency of coalition government at the time. Macdonald, Galt, and Cartier had all worked together in the past: a ministry connecting Tories from Canada West with Tories and Bleus from Canada East was not exceptional. What was exceptional was the inclusion of George Brown in the coalition. Brown and Macdonald disliked each other with some intensity. More importantly, their mutual personal feelings of animosity reflected 
differences in opinion that were shared by their respective electorates. Brown was a standardbearer for liberalism in Canada West: first in championing responsible government, and then in pushing for representation by population and the separation of church and state. ${ }^{4}$ Macdonald was less clearly an ideologue (perhaps for no other reason than that Brown's job outside of the assembly was publisher of The Globe, while Macdonald was a lawyer), and many of Macdonald's electoral supporters might have accepted some of Brown's positions. Few people who voted for Brown and his allies in the election of 1863, however, would have expected a coalition with Macdonald. His political power relied on the electoral strength of the French Catholic Bleu in Canada East, and Macdonald was unprepared to significantly alter constitutional arrangements to limit their electoral power, or to turn their supporters away. All of this would make him anathema to Brown supporters in Canada West. The French-speaking electorate in Canada East would also have wondered about the wisdom of a coalition between the Bleu and Brown. Brown's political goals prior to the coalition were, at best, likely to undermine French-Catholic power in the colony; at his worst Brown sounded like a bigot. He was likely as much anathema to Cartier's supporters as Macdonald was to Brown's.

The Great Coalition was formed with the intention of achieving significant change in government. Macdonald favoured a confederation of all of the British colonies. Brown was amenable to this proposition, but failing it, wanted to change the constitution to separate Canada West from Canada East. Cartier would accept either result, so long as any change did not interfere with the political and social rights of the French people in Canada East: essentially, Catholic control of education and other social functions, civil law, and the French language. Of the three, Macdonald was the most committed to confederation of all the colonial leaders, as his continued political relevance relied on some form of federal government extending beyond the Canadas alone.

The Great Coalition of 1864 was made up of political opponents who did not campaign in any election on the basis of the suggestion that such a coalition was a possibility (the last election had been held many months before the coalition was even formed). The coalition partners included ethnic or regional nationalists in the characters of Cartier and Brown. Moreover, Brown, at least, was a separatist who saw the destruction and reconstruction of the Canadian constitutional order, as it existed in 1864, as the only possible future for British North America.

There was some opposition to the coalition in 1864, just as there was in 2008. The strongest opposition came from the minority within the assembly left out of the coalition: the Rouge in Canada East, and J.S. Macdonald and some of his supporters among the Grits of Canada West. Peter Waite notes in his Life and Times of Confederation, for example, that Rouge papers called Cartier and his Bleu colleagues "traitors." The Conservative press in Canada West was likewise perplexed, noting how a few days before:

almost every man, woman and child, knew their political creed by heart, but are now, as it were, brought to a stand still, and all their preconceived ideas of the fitness of things and long settled opinions of men and measures knocked into pi. ${ }^{5}$

Yet Waite records the overwhelming support for the coalition from Reformers and Grits, Conservatives and Bleus. ${ }^{6}$ For all of its strangeness, the coalition seems to have been legitimate in the eyes of most Canadians of the time.

Not only was coalition not on the table in the election of 1863, neither it, nor its one big political legacy, Confederation, were ever put to a vote in Canada. The next time the electorate had a vote, it was to elect the first federal government of the new Confederation, and the provincial governments of Ontario and Québec. There was little question in the Canadas about the legitimacy of the coalitions or its creation of Confederation, then or now.

Had the Liberal-NDP coalition of 2008 come to pass, I doubt that it would have led to the political revolution for Canada that resulted from the Great Coalition of 1864. But, as a historian teaching about responsible government, 
the Great Coalition, and Confederation, I was disheartened by the absence of almost any attempt to think about, or draw links between, 1864 and $2008 .^{6}$ Failing to consider the Great Coalition of 1864 and the other coalitions between 1841 and 1867 helped to paint the 2008 coalition as illegal, illegitimate, and unprecedented, rather than as a minor replica of the coalition that helped to create modern Canada in the first place.

\section{Notes}

* Department of History \& Classics and the Faculty of Law, University of Alberta.

1 The history of Confederation has been subject to revisionist critiques in the last fifteen years, and some of what I will present here builds on that recent history. Other elements draw from the older standard telling of the Confederation story. The standard telling can be found in J.M.S. Careless, Brown of the Globe: Statesman of Confederation, 1860-1880, vol. 2 (Toronto: Dundurn Press, 1989); D.G. Creighton, John A. Macdonald: The Young Politician (Toronto: Macmillan, 1952); and D.G. Creighton, The Road to Confederation: The Emergence of Canada, 1863-1867 (Toronto: Macmillan, 1963); W.L. Morton, The Critical Years: The Union of British North America, 1857-1873 (Toronto: McClelland and Stewart, 1964); and P.B. Waite, The Life and Times of Confederation, 1864-1867: Politics, Newspapers, and the Union of British North America, 3d ed. (Toronto: Robin Brass Studio, 2001) [Life and Times]. For the revisionist account, see especially Ged Martin, Britain and the Origins of Canadian Confederation 1837-1867 (Vancouver: UBC Press, 1995); Paul Romney, Getting it Wrong: How Canadians Forgot their Past and Imperilled Confederation (Toronto: University of Toronto Press, 1999); and Andrew Smith, British Businessmen and Canadian Confederation: Constitution Making in an Era of Anglo-Globalization (Montreal: McGillQueen's University Press, 2008). Christopher Moore's 1867: How the Fathers Made a Deal (Toronto: McClelland and Stewart, 1997) falls somewhere between the two historiographies and is an excellent and engaging study of a handful of the main political actors.

2 To avoid confusion, when referring to John Sandfield Macdonald I will always identify him as J.S. Macdonald. When I use "Macdonald" alone I will be referring to John A. Macdonald. lin, Canadian Chronology (Metuchen New Jersey: The Scarecrow Press, 1970) at 34-7.

4 Under the union of Upper and Lower Canada each half of the colony had an equal number of seats in the assembly. By the 1860s the population differences between Canada East and West were significant enough that many in the West felt aggrieved by this situation.

$5 \quad$ Waite, Life and Times, supra note 1 at 47.

$6 \quad$ Ibid. at 45-9.

7 John Turley-Ewart, associate editor of the Financial Post and "a PhD in Canadian business and political history" made brief mention of the coalition in "What would Sir John A. do?" National Post (4 December 2008) A22, where he comments that: "The Province of Canada was politically dysfunctional by 1864 . Francophones feared for their cultural identity; the more numerous Anglophones pressed for more political clout through representation by population. That impasse was overcome when deeply partisan leaders such as John A. Macdonald, George Brown, George-Etienne Cartier and A.A. Dorion had the sense to take a step back from their positions in a time of crisis and work with their opponents for a mutually acceptable outcome." Alas, not only does Dr. Turley-Ewart appear to include (against history and surely his will) Dorion in the coalition, but he concludes his column by suggesting that the lesson of all of this is that the Governor General "leave the choice of who will form the government to Canadians themselves," exactly contrary the very history of the coalition. 